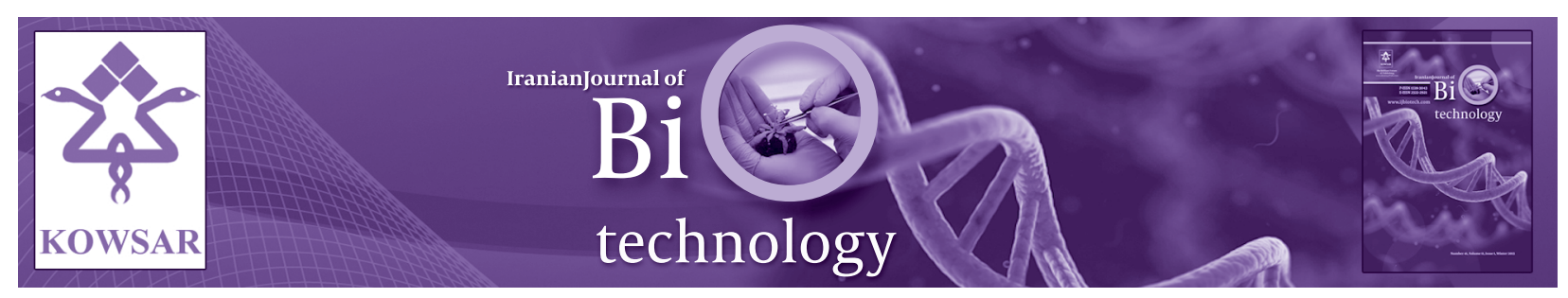

\title{
Heterologous Expression of Bovine Prochymosin in Pichia pastoris GS115
}

\author{
Fatemeh Ramezani ${ }^{1,2} \Delta$, Sara Sadr Mohammad Beigi ${ }^{1,2 \Delta}$, Gholamreza Ahmadian ${ }^{1^{*}}$, Moham- \\ madreza Soudi ${ }^{2}$, Soheila Ghandili ${ }^{1}$ \\ ${ }^{1}$ National Institute of Genetic Engineering and Biotechnology, Tehran, IR Iran \\ ${ }^{2}$ Departments of Biology, Faculty of Microbiology, Alzahra University, Tehran, IR Iran
}

\section{A R T I C L E I N F O}

\section{Article type:}

Brief Report

Article history:

Received: 28 Jun 2011

Revised: 07 Nov 2011

Accepted: 18 Apr 2012

Keywords:

Bovine Prochymosin

Cloning

Pichiapastoris

\begin{abstract}
A B S T R A C T
Background: Aqueous extract of dried fourth stomach of unweaned bovine contains prochymosin, that subsequently is converted to active chymosin, a milk-coagulating enzyme in the cheese industry. Recombinant chymosin has been found to be a suitable replacement for natural bovine chymosin. Meanwhile it possesses several advantages to other plant, fungal and bacterial milk-clotting enzymes.

objectives: In present research we evaluate the expression of this critical enzyme in a eukaryotic system for future use in cheese industry.

Materials and Methods: We have cloned bovine prochymosin gene in methylotrophic yeast, $P$. pastoris, using pPIC9K as an expression vector. The recombinant plasmid was transformed into the host by electroporation, and it was expressed in optimum conditions (temperature $29^{\circ} \mathrm{C}, 200 \mathrm{rpm}, 2 \%$ methanol for induction, and 5 days of incubation). Transcription and expression of the recombinant prochymosin was evaluated by the reverse transcription polymerase chain reaction (RT-PCR), sodium dodecyl sulfate polyacrylamide gel electrophoresis (SDS-PAGE) analysis as well as western blotting and enzyme-linked immunosorbent assay (ELISA).

Results: In optimum conditions, only a low level of this heterologous protein was detected using ELISA method and subsequently confirmed by RT-PCR.

Conclusions: Since it has been reported that P. pastoris is an appropriate host for the expression of recombinant proteins, a low level of expression of prochymosin in this host should be explored in our future research. Published by Kowsar Corp, 2013. cc 3.0.
\end{abstract}

- Implication for health policy/practice/research/medical education:

Eukaryotic expression of an important enzyme used in dairy industry.

\section{- Please cite this paper as:}

Ramezani F, Sadr Mohammad Beigi S, Ahmadian GR, Soudi MR, Ghandili S. Heterologous Expression of Bovine Prochymosin in Pichia pastoris GS115. Iran J Biotech. 2013: 11(1): 59-63. DOI: 10.5812/ijb.9228

\section{Background}

Chymosin is an aspartic proteinase (EC 3.4.23.4) that is responsible for the coagulation of milk in the fourth stomach of unweaned calves (1). This enzyme (35.6 kDa) is secreted by the cells of the gastric mucosa as an inactive precursor, known as prochymosin $(40.8 \mathrm{kDa})$. In the acidic conditions of the lumen, it is subsequently converted to chymosin, by autocatalytic cleavage of the 42-amino

\footnotetext{
* Corresponding author: Gholamreza Ahmadian, National Institute of Genetic Engineering and Biotechnology, P.O. Box: 14965/161, Tehran, IR Iran. Tel: +982144580351, Fax:+98-2144580395, E-mail: ahmadian@nigeb.ac.ir

${ }^{\Delta}$ The first two authors are considered as the first author
}

DOI: $10.5812 /$ ijb.9228

Copyright (C) 2013, National Institute of Genetic Engineering and Biotechnology; Published by Kowsar Corp.

This is an Open Access article distributed under the terms of the Creative Commons Attribution License (http://creativecommons.org/licenses/by/3.0), which permits unrestricted use, distribution, and reproduction in any medium, provided the original work is properly cited. 
acid N-terminal prosequence (2). Chymosin is used extensively in cheese production because of specific cleavage of $\kappa$-casein, at the Phe105 - Met106 bond. Due to a shortage of calf stomachs, it is possible to clone the gene for calf chymosin in appropriate vectors and express them in different hosts including E. coli, (Chy-Max, Pfizer, Milwaukee, USA), Kluyveromyces lactis (Maxiren, Gist-Brocades, Delft, Holland) and Aspergillus niger var. awamori (Chymogen, Genencor, Palo Alto, CA, USA) (3). The methylotrophic yeast Pichia pastoris is suitable for the expression of eukaryotic proteins. P. pastoris has numerous advantages of higher eukaryotic expression systems, but the ease of its genetic manipulation is similar to E. coli and S. cerevisiae. The other advantage of $P$. pastoris is that the ultrahigh cell densities are easily achieved at minimal costs $(4,5)$. The $P$. pastoris expression system has been used successfully for the production of different recombinant heterologous proteins, such as A. awamori glucoamylase, Aspergillus oryzae Tannase, Rhizopus oryzae lipase, E. coli Lgalactosidase, dengue virus structural protein, human granulocyte-colony stimulating factor and human eosinophil peroxidase $(6,7)$. In most cases, the alcohol oxidase I promoter (PAOXI) was used for the expression of heterologous genes, and vectors integrate into the Pichia genome. PAOXI is completely repressed when cells have used glucose as carbon source, and induced in the presence of methanol (4).

\section{Objectives}

Ahmadian et al. (1) have shown that the expression of recombinant prochymosin in E.coli system was acceptable, but the formation of inclusion bodies and the necessity for refolding and activation of the produced enzyme, caused to evaluate the expression of this important enzyme in a eukaryotic system for meet the dairy industry's needs.

\section{Materials and Methods}

In the present study, the bovine prochymosin gene, was cloned in pPIC9K, at NotI-SnaBI site, under the control of alcohol oxidase I promoter (PAOXI) and with Saccharomyces cerevisiae alpha factors $(\alpha-\mathrm{MF})$ to secrete proteins into the medium. The recombinant plasmid (pPIC9K) Prochymosin) was transformed into E. coli strain TOP10 for amplification of plasmid. Approximately $10 \mu \mathrm{g}$ of recombinant expression plasmid was linearized with SacI. Transformation of $P$. pastoris strain GS115 was made using electroporation following manufacturer's recommendations (Invitrogen) by a Gene Pulser (Bio-Rad) using $80 \mu \mathrm{g}$ of competent cells. The recombinant GS115 strain was cultured on Yeast Extract Peptone Dextrose (YPD) Medium plus $2 \%$ agar. The strain GS115 has a mutation in the histidinol dehydrogenase gene (his4) that prevents it from synthesizing histidine. The expression plasmid carries the HIS4 gene that complements his4 in this host, so the transformed cells are selected for their ability to grow on a histidine-deficient medium (Minimal Dextrose or MD: $1.34 \%$ yeast nitrogen base without amino acids, $4 \times 10^{-5} \%$ biotin, $2 \%$ dextrose and $2 \%$ agar) by incubation at $28-30^{\circ} \mathrm{C}$ for 4 days. PCR amplification was used to verify the prochymosin gene integration into the AOX1 locus in the chromosome of the transformed P. pastoris. For PCR amplification, the reactions were carried out in a GeneAmp PCR system 9700 (PE Applied Biosystems) with conditions of denaturation at $94^{\circ} \mathrm{C}$ for $3 \mathrm{~min} ; 30$ cycles for amplification (at $94^{\circ} \mathrm{C} / 60 \mathrm{sec}, 53^{\circ} \mathrm{C} / 60 \mathrm{sec}$, and $72^{\circ} \mathrm{C} / 150 \mathrm{sec}$ ); and the final extension at $72^{\circ} \mathrm{C}$ for $300 \mathrm{sec}$. The reaction mixture contained $0.2 \mathrm{mM}$ of each primers (F primer $5^{\prime}$-AOX1: $5^{-}$-GACTGGTTCCAATTGACAAGC-3 ${ }^{\prime}$; and R primer $3^{\prime}$-AOX1: $5^{\prime}$-GCAAATGGCATTCTGACATCC-3') $, 2 \mathrm{mM} \mathrm{MgCl}_{2}, 2.5 \mathrm{U}$ of PFU DNA polymerase (Fermentas) and extracted genome of recombinant pichia strains as a template. Gene insertion events at the AOX1 (GS115) loci arise from a single crossover event between the loci and any of the three AOX1 regions on the vector. These events result in the insertion of one or more copies of the vector upstream or downstream of the AOX1. The phenotype of such a transformant is $\mathrm{His}^{+} \mathrm{Mut}^{+}$that can utilize methanol quickly. For confirmation of gene insertion, two different PCR products from two clones were selected and their nucleotide sequences were determined (MWG, Germany). The pPIC9K vector contains bacterial kanamycin gene that confers resistance to geneticin in P. pastoris. Because of the genetic linkage between the kanamycin gene and the "expression cassette", a single copy of pPIC9K integrated into the Pichia genome confers $\sim 0.25 \mathrm{mg} \cdot \mathrm{mL}^{-1}$ resistance to geneticin. Multiple integrated copies of pPIC9K can increase the geneticin resistance level from $0.5 \mathrm{mg} \cdot \mathrm{mL}^{-1}(1-2$ copies) up to $4 \mathrm{mg} \cdot \mathrm{mL}^{-1}$ ( 7 - 12 copies). Protein expression may upsurge as a result of the gene dosage effect; it involves growing colonies in microtiter plates until all colonies reach to the same density. The colonies were then spotted on the YPD-geneticin plates (in different concentrations of geneticin: $0.25,0.5,1.0$, and $2.0 \mathrm{mg} \cdot \mathrm{mL}^{-1}$ ) and scored for geneticin resistancy. For expression of the recombinant protein, selected colonies were inoculated into $10 \mathrm{~mL}$ Buffered Minimal Glycerol-complex (BMGY) Medium (1\% (w/v) yeast extract, $2 \%(\mathrm{w} / \mathrm{v})$ peptone, $0.1 \mathrm{M}$ phosphate buffer ( $\mathrm{pH} 6.0$ ), 1.34\% yeast nitrogen base, $4 \times 10^{-5} \%$ biotin and $1 \%(\mathrm{v} / \mathrm{v})$ glycerol), and were incubated at $28^{\circ} \mathrm{C}$ in a shaker incubator at $180 \mathrm{rpm}$ until it reached A600 of 2-6 as per the manufacturer's recommendation. The cells were harvested by centrifugation and resuspended in $50 \mathrm{~mL}$ of Buffered Minimal Methanol-complex (BMMY) Medium (the same as BMGY except that glycerol was replaced by $2 \% \mathrm{v} / \mathrm{v}$ Methanol), to A600 of 1.0 in a 250 $\mathrm{mL}$ conical flask. Incubation was continued at $29^{\circ} \mathrm{C}$ in a shaker incubator at $200 \mathrm{rpm}$ with the addition of methanol every 24 hours to achieve a concentration of $2 \%$ to sustain the induction for 5 days (based on our optimization experiments). Samples with high copy numbers of 
the prochymosin gene were analyzed for transcription of the prochymosin gene. RNA was extracted from the disrupted cells according to the RNAfast protocol following the manufacturer's recommendation. Isolated RNA was used as the template in reverse transcription reaction. First strand cDNA synthesis was performed using Revert AidTM First Strand cDNA Synthesis Kit (Fermentase). The cDNA produced was used as a template for amplification by PCR. After every induction, recombinant proteins secreted into the medium, were precipitated using ammonium sulphate and 80\% TCA solutions. Protein samples were dialyzed against a solution of $100 \mathrm{mM}$ Tris-Hcl $\mathrm{pH}$ 8.0 for removing the salts. The solution was loaded onto Ni-NTA column for purifying 6XHis-tagged proteins. The protein samples were separated by electrophoresis on a 12\% SDS-PAGE gel. The expression of prochymosin was determined using a monoclonal anti-6Xhis-tag antibody (Serotec, USA) as a first antibody $\left(2 \mu \mathrm{g} \cdot \mathrm{mL}^{-1}\right)$ and a 1:2000 dilution of polyclonal rabbit anti-mouse immunoglobulin/HRP (Roche, Germany) as a second through western blotting. Finally, protein samples were visualized using $\mathrm{DAB} / \mathrm{H}_{2} \mathrm{O}_{2}$ chromogen-substrate solution. Expression of the recombinant prochymosin was also confirmed by Enzyme Linked Immunosorbent Assay (ELISA) using anti-prochymosin polyclonal antibody as a first antibody (of 1/500 in PBS) and a polyclonal rabbit anti-mouse immunoglobulin/HRP (diluted 1:2000 in PBS) as a second. Finally, protein samples were visualized using freshly prepared chromogen-substrate mixture $\left(\mathrm{ABTS} / \mathrm{H}_{2} \mathrm{O}_{2}\right)$. The positive results are shown as green color, but we used ELISA-reader (for reading absorption in $405 \mathrm{~nm}$ ) for quantitative evaluation.

\section{Results}

To confirm the transformation of recombinant plasmid (pPIC9K/ the approximately $1100 \mathrm{bp}$ fragment of bovine prochymosin gene which fused to six histidine tag at its 3' end) in E. coli strain TOP10, we have used digest check as described in Figure 1. In results of PCR experiments, two expected bands (a $1.5 \mathrm{~kb}$ and another $2.2 \mathrm{~kb}$ ) were detected (Figure 2A). The results of sequencing showed that recombinant prochymosin is the same as Bos taurus chymosin precursor (mRNA, complete cds) present in the gene bank (Accession number: FJ768675.1), and also the one which was previously cloned and sequenced by Ahmadian et al. (1). In our studies only a few high-geneticin resistant colonies were observed (colonies number 3, 6, 7, 8,14 , and 24), which were smaller in sizes than low-geneticin resistant colonies but their morphology were similar. Colony number 6 , which has grown on $2 \mathrm{mg} \cdot \mathrm{mL}^{-1}$ geneticin, was selected for expression of recombinant protein in a shake flask; and colony number 10 for comparison.
Figure 1. The Presence of Target Gene Was Checked by Digesting of Plasmids with EcoRI and NotI

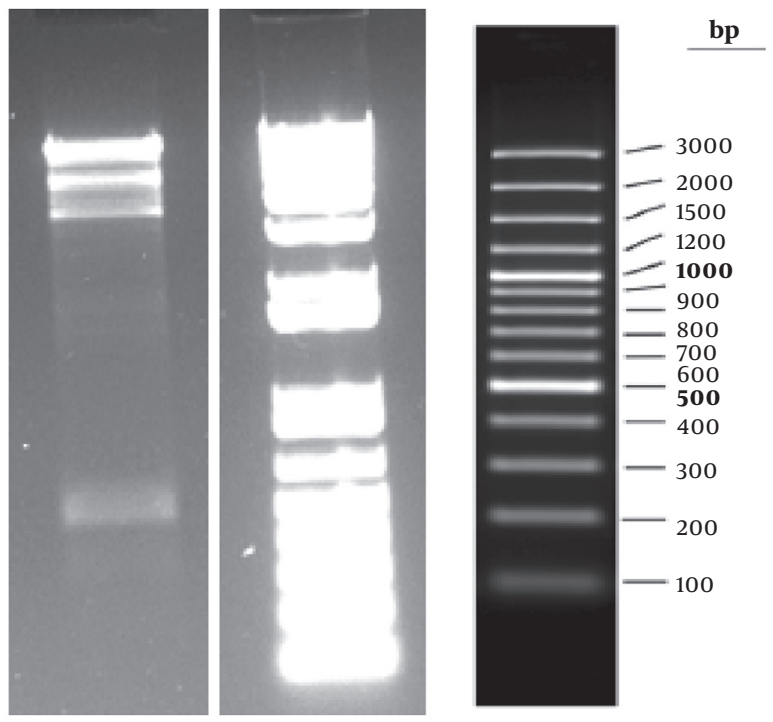

As EcoRI has a restriction site at nucleotide number 478 in prochymosin gene, and NotI at $3^{\prime}$ end of the gene; cleavage of recombinant plasmid with these two enzymes produced a $550 \mathrm{bp}$ fragment.

Figure 2. The Integration of Target Gene into the Genome of GS115 Was Determined by PCR and RT-PCR Amplification

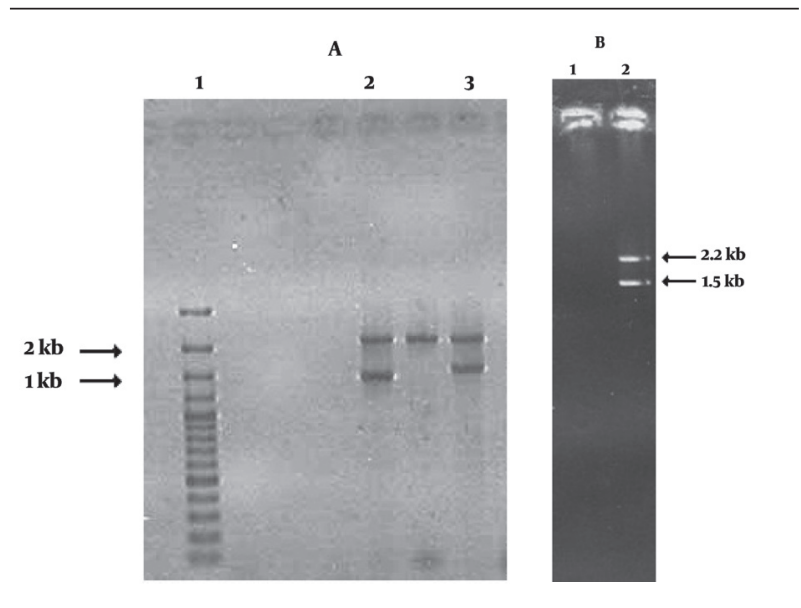

A) PCR amplification: Lane 1 contains a 1 kb ladder. Lane 2 shows the wildtype AOX1 gene from GS115. Lane 3 shows the native AOX1 gene of yeast genome $(2.2 \mathrm{~kb})$ and a $1.5 \mathrm{~kb}$ product containing the gene of interest (prochymosin, $1.1 \mathrm{~kb}$ ) flanked by AOX1 sequences (from GS115 or pPIC9K); B) RT-PCR analysis: Lane1 shows PCR of extracted mRNA without reverse transcription with specific primers (negative control). Lane2 shows PCR of Prochymosin cDNA that has been made from prochymosin mRNA with specific primers (the result is same as part A). 
The expression of precipitated $40 \mathrm{kDa}$ protein (prochymosin) from the supernatant of growing medium of the colony number 6 was detected only with ELISA analysis as a green color with A405 $=0.051$ with an average of three repeats. The low level of expression was below the limit of detection sensitivity of Western blotting. The colony number 10 didn't show any detectable expression of target protein. The result of RT-PCR analysis was same as the PCR amplification of target gene as described previously (2 bands), and confirms the result of ELISA analysis (Figure $2 \mathrm{~B})$.

\section{Discussion}

Hence, in optimum conditions for the expression of prochymosin gene in P. pastoris, only a low level of recombinant protein was detected using ELISA method and subsequently confirmed by RT-PCR. Although it has been reported that $P$. pastoris represents an appropriate host for the expression of recombinant proteins, the low level of expression in this host could be attributed to several factors. These potential impediments include, the lack of consistency of codon usage of the bovine and pichia (8), copy number of the gene (9), the efficiency and strength of promoters (10), efficiency of translation signals (11) and signal peptides (12), processing and folding in the endoplasmic reticulum and Golgi apparatus (13), environmental factors of expression (14), extracellular secretion $(15)$, and protein turnover by proteolysis $(16,17)$. As the recombinant, colony number 6 is high geneticin resistant (which grown on $2 \mathrm{mg} / \mathrm{mL}$ of this Antibiotic), the copy number of the gene was not restrictive for recombinant protein production. We have used some protease inhibitors such as EDTA ( $5 \mathrm{mM}$ ) to reduce proteolysis in production process. Therefore, it remains to be determined which of these factors resulted in the enhancement of prochymosin production existing in the machinery of P. pastoris. The fermentation can be easily scaled up to achieve greater level of expression. Meanwhile, the parameters influencing the growth and protein productivity of P. pastoris (such as $\mathrm{pH}$, aeration, carbon and nitrogen source feed rate) can be controlled. According to some reports, the expression level could be increased by growing the recombinant Pichia in a fermentor, as the higher cell density could improve the production rate of prochymosin. In the fermentor, 3 - 5 times higher transcription levels can be obtained as a consequence of the controlled methanol concentration (18). Additionally, it is shown that codon optimization of prochymosin gene can further improve the expression level $(8,19)$.

\section{Acknowledgments}

The authors thank the National Institute of Genetic Engineering and Biotechnology (NIGEB) of Iran for support and funding. We would like to thank Dr. Mehdi ShamsAra, faculty member at the NIGEB for his useful com- ments and Mr. Mostafa Keshavarz for his experimental assistance during the course of this research.

\section{Authors' Contribution}

Gholamreza Ahmadian was corresponding author. Sara Sadr Mohammad Beigi wrote the manuscript and is guarantor. Sara Sadr Mohammad Beigi and Fatemeh Ramezani equal contributed to the development of the protocol, abstracted data, and repaired the manuscript. Soheila Ghandili and Mohammadreza Soudi were technical assistant and advisor respectively.

\section{Financial Disclosure}

We have no financial interests related to the material in the manuscript.

\section{Funding/ Support}

This project was supported by grant No.432 from National Institute of Genetic Engineering and Biotechnology, Tehran, I.R. Iran.

\section{References}

1. Fox PF, McSweeney PLH. Rennets: their role in milk coagulation and cheese ripening. In: Law BA, editor. Microbiol Biochem Cheese and Fermented MilkJ. London: Blackie Academic and Professional; 1999. p. 1-49.

2. Foltmann B. Prochymosin and chymosin (prorennin and rennin). In: E. G, Perlmann LL, editors. Met Enzymol: Academic Press; 1970. p. 421-36.

3. Badiefar L, Ahmadian G, Asgarani E, Ghandili S, Salek Esfahani M, Khodabandeh M. Optimization of conditions for expression and activation of a splice variant of prochymosin lacking exon 6 in Escherichia coli. Int J Dairy Tech. 2009;62(2):265-71.

4. Ahn J, Hong J, Lee H, Park M, Lee E, Kim C, et al. Translation elongation factor 1-alpha gene from Pichia pastoris: molecular cloning, sequence, and use of its promoter. Appl Microbiol Biotechnol. 2007;74(3):601-8

5. Skoko N, Argamante B, Grujicic NK, Tisminetzky SG, Glisin V, Ljubijankic G. Expression and characterization of human interferon-beta1 in the methylotrophic yeast Pichia pastoris. Biotechnol Appl Biochem. 2003;38(Pt 3):257-65.

6. Saeedinia A, Shamsara M, Bahrami A, Zeinoddini M, NaseeriKhalili MA, Mohammadi R, et al. Heterologous expression of human granulocyte-colony stimulating factor in Pichia pastoris. Biotechnol J. 2008;7(3):569-73.

7. Ciaccio C, Gambacurta A, De Sanctis G, Spagnolo D, Sakarikou C, Petrella G, et al. rhEPO (recombinant human eosinophil peroxidase): expression in Pichia pastoris and biochemical characterization. Biochem J. 2006;395(2):295-301.

8. Outchkourov NS, Stiekema WJ, Jongsma MA. Optimization of the expression of equistatin in Pichia pastoris. Protein Expr Purif. 2002;24(1):18-24.

9. Vassileva A, Chugh DA, Swaminathan S, Khanna N. Effect of copy number on the expression levels of hepatitis B surface antigen in the methylotrophic yeast Pichia pastoris. Protein Expr Purif. 2001;21(1):71-80.

10. Sears IB, O'Connor J, Rossanese OW, Glick BS. A versatile set of vectors for constitutive and regulated gene expression in Pichia pastoris. Yeast. 1998;14(8):783-90.

11. Cavener DR, Ray SC. Eukaryotic start and stop translation sites. Nucleic Acids Res. 1991;19(12):3185-92.

12. Raemaekers RJ, de Muro L, Gatehouse JA, Fordham-Skelton AP. Functional phytohemagglutinin (PHA) and Galanthus nivalis 
agglutinin (GNA) expressed in Pichia pastoris correct N-terminal processing and secretion of heterologous proteins expressed using the PHA-E signal peptide. Eur J Biochem. 1999;265(1):394-403.

13. Kowalski JM, Parekh RN, Mao J, Wittrup KD. Protein folding stability can determine the efficiency of escape from endoplasmic reticulum quality control. J Biol Chem. 1998;273(31):19453-8.

14. Villatte F, Hussein AS, Bachmann TT, Schmid RD. Expression level of heterologous proteins in Pichia pastoris is influenced by flask design. Appl Microbiol Biotechnol. 2001;55(4):463-5.

15. Rossini D, Porro D, Brambilla L, Venturini M, Ranzi BM, Vanoni $\mathrm{M}$, et al. In Saccharomyces cerevisiae, protein secretion into the growth medium depends on environmental factors. Yeast.
1993;9(1):77-84.

16. Cregg JM, Cereghino JL, Shi J, Higgins DR. Recombinant protein expression in Pichia pastoris. Mol Biotechnol. 2000;16(1):23-52.

17. Zahri S, Zamani MR, Motallebi M, Sadeghi M. Cloning and characterization of cbhII gene from Trichoderma parceramosum and its expression in Pichia pastoris. IranJ Biotech. 2005;3(4):204-15.

18. Cereghino JL, Cregg JM. Heterologous protein expression in the methylotrophic yeast Pichia pastoris. FEMS Microbiol Rev. 2000;24(1):45-66.

19. Feng Z, Zhang L, Han X, Zhang Y. Codon optimization of the calf prochymosin gene and its expression in Kluyveromyces lactis. World J Microb Biotech. 2010;26(5):895-901. 